\begin{tabular}{|c|c|c|}
\hline ב & $\begin{array}{l}\text { International Journal of Current Research in } \\
\text { Biosciences and Plant Biology }\end{array}$ & $y=$ \\
\hline & Volume 7 • Number 11 (November-2020) • ISSN: 2349-8080 (Online) & \\
\hline $\begin{array}{l}\text { EXCELLENT } \\
\text { PUBLISHERS }\end{array}$ & Journal homepage: www.ijcrbp.com & \\
\hline
\end{tabular}

Review Article

doi: https://doi.org/10.20546/ijcrbp.2020.711.003

\title{
Safed musli (Chlorophytum borivilianum): Ethnobotany, phytochemistry and pharmacological updates
}

\author{
Ravindra B. Malabadi* and Raju K. Chalannavar
}

Department of Applied Botany, Mangalore University, Mangalagangotri-574199, Mangalore, Karnataka State, India

${ }^{*}$ Corresponding author; e-mail: rbmalabadi_b3g@yahoo.com

\begin{tabular}{|c|c|}
\hline Arti & ABSTRACT \\
\hline & \multirow{9}{*}{$\begin{array}{l}\text { Safed musli (Chlorophytum borivilianum) belongs to a family Lilliaceae is one of the } \\
\text { important endangered Indian herbal medicine known for adoptogenic and aphrodisiac } \\
\text { properties acts as rejuvenator. Traditionally, Safed musli (Chlorophytum borivilianum) } \\
\text { root has been used to treat male impotence, oligozoospermia and erectile dysfunction. } \\
\text { Roots of safed musali are known to improve male reproductive performance by } \\
\text { increasing the testosterone level in male partner and consumption of green leaves as } \\
\text { immunity booster. Safed musli (Chlorophytum borivilianum) is a highly valued } \\
\text { medicinal plant in India and is considered as "white gold" in Indian system of } \\
\text { Ayurveda. Safed musli (Chlorophytum borivilianum) is a rich source of over } 25 \\
\text { alkaloids, vitamins, minerals, proteins, carbohydrates, steroids, saponins and } \\
\text { polysaccharides. A number of health tonics were prepared from safed musli. This } \\
\text { review paper highlights latest updates on ethnobotany and pharmacological activities of } \\
\text { safed musli (Chlorophytum borivilianum). }\end{array}$} \\
\hline & \\
\hline Ke & \\
\hline & \\
\hline & \\
\hline & \\
\hline & \\
\hline & \\
\hline & \\
\hline
\end{tabular}

\section{Introduction}

Chlorophytum borivilianum (Kannada: Dravanti) commonly known as safed musli is an important rare endangered tiny annual herb belongs to family Lilliaceae (Bhat et al., 2018). Safed musli is known for aphrodisiac, immunomodulatory activity and anti-ageing properties (Kothari, 2004; Chakraborthy and Aeri, 2009; Sharma and Mazumdar, 2012; Singh et al., 2012; Rungsung et al., 2013; Kenjale et al., 2008 Bhat et al., 2018). The centre of its origin lies in tropical and subtropical Africa (Chakraborthy and Aeri, 2009). Traditionally, C. borivilianum tuberous root has been used for the treatment of male impotence, oligozoospermia and erectile dysfunction since the safed musali is very rich in glycosides. It works very well in curing impotency (Sharma and Mazumdar, 2012; Desale, 2013; Giribabu et al., 2014; Kenjale et al., 2008; Bhat et al., 2018).

Safed musli is used for the production of male sex hormone testosterone and also used for the effective execution of adrenal gland which is very important for sexual arousal (Desale, 2013). Safed musli is particularly used for individuals with low sperm count and low libido which will improve sexual weakness (Desale, 2013). Therefore, safed musli is an excellent traditional herbal remedy for several other male conditions, including infertility, oligospermia or low sperm count, premature ejaculation, and physical weakness. It has the 
ability to increase the quality and quantity of male sperm count, semen motility, and thereby successful fertility could be expected (Desale, 2013). The rhizome powder of safed musli is also consumed as a nutritive tonic with milk in case of seminal weakness, impotency, used to cure fever and leucorrhoea (Bhat et al., 2018; Sharma and Mazumdar, 2012). The consumption of safed musli also increases the testosterone level in male partner. Testosterone is an anabolic steroid in males plays an important role in the development of male reproductive tissues such as testes and prostate.

\section{Medicinal properties of safed musli}

Because of its aphrodisial properties, and spermatogenic potential, safed musli has been mainly identified as a sex vitalizer or Desi viagra or 'Herbal viagra' (Sharma and Mazumdar, 2012; Singh et al., 2012; Thakur and Dixit, 2006; Giribabu et al., 2014; Kenjale et al., 2008). Safed musli was also found to be significant protection against stress induced changes. It also cures many physical illness and weakness (Sharma and Mazumdar, 2012; Kothari, 2004).

Chlorophytum borivilianum (safed musli) popularly known as the Indian Ginseng which is traditionally used as a health promotive tonic, an adoptogenic drug, antioxidant, anti-arthritic, antiinflammatory, antipyretic, galactogogue, hypercholesteremia, hepatoprotective, hypolipidemic, anthelmintic, antiulcer, antistress, antiviral, antifungal, anti-tumour, anti-mutagenic, antidiabetic, antimicrobial, larvicidal activity, anticancer, anti- ageing process, aphrodisiac, and total rejuvenator (Bhat et al., 2018; Deore and Khadabadi, 2007, 2008a, 2008b, 2009, 2010; Akki and Patil, 2006; Singh et al., 2012; Sharma and Mazumdar, 2012; Rungsung et al., 2013; Elizabeth, 2001; Singh and Chauhan, 2003; Thakur and Dixit, 2006).

The tuberous root of Chlorophytum borivilianum (safed musli) are a constituent of 'Chyawanprash' an outstanding rejuvenator (Singh et al., 2012). In Indian system of Ayurveda, Safed musli (Chlorophytum borivilianum) is considered as a "Divya Aushad" or "Rasayana" a nature's gift and God-given wonder drug for the treatment of health disorders as well as general debility (Sharma and
Mazumdar, 2012; Rungsung et al., 2013; Kenjale et al., 2008).

Around 300 species of Chlorophytum have been found in tropical and sub tropical region throughout world and seventeen species of Chlorophytum had been reported in India (Mayank and Dixit, 2008; Sharma and Mazumdar, 2012; Singh et al., 2012; Rungsung et al., 2013; Elizabeth, 2001; Singh and Chauhan, 2003). There are 8 common safed musali found in different parts of India such as 1) Chlorophytum borivilianum, 2) Chlorophytum arundinaceum 3) Chlorophytum tuberosum 4) Chlorophytum malabericum 5) Chlorophytum attenuatum 6) Chlorophytum breviscapum 7) Chlorophytum filicinus 8) Chlorophytum gonoclados (Mayank and Dixit, 2008; Sharma and Mazumdar, 2012).

In India, it is widely distributed in Assam, Gujarat, Madhy Pradesh, Rajasthan, found in Western Ghat Forests of Karnataka, Konkana Maharashtra, Chhatisgarh, Eastern Himalayas, and Tamilnadu. However, over exploitation of Chlorophytum borivilianum has decreased its distribution and recorded as one of the endangered plant species (Sharma and Mazumdar, 2012; Singh et al., 2012). Therefore, cultivation of Chlorophytum borivilianum in agriculture land during the month of April-May as a cash crop is often indeed in some parts of Gujarat, Maharashtra, Tamil Nadu and Karnataka to meet commercial demand in national and international market for pharmaceutical industry (Elizabeth, 2001; Singh et al., 2012; Singh and Chauhan, 2003; Sharma and Mazumdar, 2012; Kothari and Sigh, 2003). In general safed musli tuberous roots were kept in the field for one month before harvesting since this turn the colour of the tuberous roots into dark brown which will also increase the medicinal value of the tubers (Kothari and Sigh, 2003). Harvesting tuberous roots of Chlorophytum borivilianum (safed musli) is done in the month of January-February (Singh et al., 2012; Rungsung et al., 2013; Singh and Chauhan, 2003; Elizabeth, 2001; Kothari and Sigh, 2003). Safed musli is propagated by using tubers and seeds. However, seed germination of Chlorophytum borivilianum is very low (10-14\%) (Kothari and Sigh, 2003). Furthermore, traditional method of propagation using tuberous root was found to be time consuming (Kothari and Sigh, 2003). Another problem is the overexploitations of 
tuberous root due to increased commercial demand have decreased the availability of tuberous root for replanting. Hence in vitro technique of shoot regeneration could be an efficient alternative means of propagating the species (Ashraf et al., 2014; Lattoo et al., 2006; Purohit et al., 1994; Samantaray et al., 2009; Haque and Bera, 2011; Shrivastava et al., 2016; Kumar et al., 2018).

Safed musli is also used in the treatment of rheumatism, the leaves were consumed as vegetable, as an expectorant, in various culinary preparations, and a herbal remedy for knee pain (Singh et al., 2012; Sharma and Mazumdar, 2012; Kothari, 2004; Haque and Bera, 2011). Root powder increases the lactation amongst the feeding mothers and lactating cows (Sharma and Mazumdar, 2012; Singh et al. 2012). In addition to this, stem, cladodes, seeds and rhizomes of safed musli were also very important in Indian and Unani traditional medicinal remedies for treatment of spermatorrhoea, chronic leucorrhoea, diarrhoea, dysentery, general debility, senile pruritus, asthma and fatigue (Sharma and Mazumdar, 2012).

A combination of safed musli leaves with other herbs makes the human body resistant against the attack of sex related diseases and also delays the menopause (Sharma and Mazumdar, 2012; Kenjale et al., 2008; Kothari, 2004; Desale, 2013; Haque and Bera, 2011). Safed musli, a potent ayurvedic aphrodisiac herb with multiple functions in male partner are (Desale, 2013) 1) Controls erectile dysfunction 2) Sperm count and density vis-a-vis motility was increased as a result of elevation in serum testosterone levels 3) Cures premature ejaculation and increases the volume and quality of ejaculation. 4) Booster for extra energy for good health. 5) Improves the semen quality. 6) Increases sperm count substantially which plays a vital role in fertility (Desale, 2013). On the other hand the consumption of safed musali in female partner improves overall health with multiple functions such as 1) Checks urinary tract infections; 2) Checks excessive menstrual bleeding 3) Checks the menopause (Desale, 2013).

Erectile dysfunction (ED) generally known as male impotency is a major health disorder affecting reproductive organ in male partner (Saxena et al.
2012; Sumalatha et al. 2010; Yakubu et al. 2008). Erectile dysfunction (ED) is mainly due to dietary factors, psychological disorders, androgen deficiencies (testosterone deficiency, hyperprolactinemia), chronic medical conditions (diabetes, hypertension, vascular insufficiency (atherosclerosis, venous leakage), penile disease (Peyronie's, priapism, phinosis, smooth muscle dysfunction), pelvic surgery (to correct arterial or inflow disorder), neurological disorders (Parkinson's disease, stroke, cerebral trauma, Alzheimer's spinal cord or nerve injury), drugs (side-effects) (anti-hypertensives, central agents, psychiatric medications, antiulcer, antidepressants and anti-androgens), life style (chronic alcohol abuse, cigarette smoking), ageing (decrease in hormonal level with age) and systemic diseases (cardiac, hepatic, renal pulmonary, cancer, metabolic, post-organ transplant) (Saxena et al. 2012), and might be due to high levels of synthetic hormones (known as Xenoestrogens) in our diet/environment (Saxena et al. 2012).

Furthermore, other factors which influence Erectile dysfunction (ED) are nutritionally imbalanced diet resulting from poor quality of produces; and extremely low levels of testosterone (Saxena et al., 2012). Conventional medicine for curing Erectile dysfunction (ED) are either surgery or a drugs such as Erecaid, Viagra, Cialis and Levitra or testosterone. In addition to this penile injections of papaverine or prostaglandin were also used to correct the male impotency (Saxena et al., 2012).

Good health is an important determinant of quality of life (Saxena et al. 2012). The use of allopathic drugs has resulted in the adverse side effects on the human body and thus limit the use of such drugs (Saxena et al., 2012; Sumalatha et al., 2010; Yakubu et al., 2008). Therefore, the use of herbal drugs could be used as an alternative chief herbal medication. Many herbal drugs were used for the treatment of male impotency (Erectile dysfunction) (Saxena et al., 2012; Sumalatha et al., 2010; Yakubu et al., 2008).

In Indian traditional herbal therapy, oral consumption of different parts of Chlorophytum borivilianum (safed musli) is considered as one of the potential medicine for male impotency (Saxena et al., 2012). Dried tubers were also used as a curative for pre-natal and post-natal illness, 
restorative and a strong health tonic and sexual debilities (Sharma and Mazumdar, 2012; Haque and Bera, 2011).

\section{Phytochemicals in safed musli}

In India, traditional use of herbal medicines known as Ayurveda is being passed from one generation to generation due to many reasons such as availability, acceptability, compatibility, and affordability (Malabadi, 2008; Malabadi and Vijayakumar, 2008; Malabadi et al., 2009, 2010a, 2010b; Malabadi et al., 2011, 2012a, 2012b, 2012c, 2012d; Malabadi et al., 2016a, 2016b, 2016c, 2016d, 2016e; Malabadi et al., 2017a, 2017b). The phytochemical constituents of safed musali are carbohydrates, vitamins, proteins and 25 alkaloids, saponins and abundant amount of mucilage (Sharma and Mazumdar, 2012; Singh et al., 2012). Furthermore, stigmasterol and saponin named as furostanol and Chlorophytoside-I (3b, 5a, 22R, $25 \mathrm{R})$ - 26 - ( $\beta$-Dglucopyranosyloxy)-22-hydroxyfurostan-12-one-3yl-O- $\beta$-D-galactopyranosyl-(1-

4)-glucopyranoside has been isolated from safed musali (Singh et al., 2012; Deore and Khadabadi, 2007, 2008a, 2008b, 2009, 2010). Fructooligopolysaccharide has been isolated and evaluated for antidiabetic activity (Deore and Khadabadi, 2008a, 2008b; Haque and Bera, 2011). Plant mucilage are pharmaceutically important polysaccharide with wide range of applications such as thickening, binding, disintegrating, suspending, emulsifying, stabilizing, and gelling agents. They have been also used as matrices for sustained and control release drugs (Deore and Khadabadi, 2008a, 2008b).

\section{Other medicinal plants used in the treatment of male impotency}

The herbal medicinal plants used in the treatment of male impotency are: 1) Allium sativum L. (Garlic, Family-Liliaceae; parts used- bulb), 2) Asparagus racemosus Willd. (Asparagus, FamilyLiliaceae; parts used-root), 3) Boerhavia diffusa L. (Punarnava, Family-Nyctaginaceae; parts used-root), 4) Cocculs cardifolia Linn. (Guduchi, Family-Menispermaceae parts used-stem, leaf, root), 5) Fadogia agrestis Schweinf. Ex Heim (Black aphrodisiac, Family-Rubiaceae; parts used- stem), 6) Myristica fragrans Houtt Nutmeg, (Family- Myristicaceae; parts used- seed), 7) Panax ginseng (Ginseng, FamilyAraliaceae, parts used-root), 8) Turnera aphrodisiaca (Damiana, Family- Trneraceae; areal part used), 9) Withania somnifera Linn. (Ashwagandha, Family- Solanaceae; parts usedleaf, root), 10) Pausinystalia yohimbe (Yohimbine, Family-Rubiaceae; parts used-bark), 11) Ginkgo biloba (Ginkgo; Ginkgoaceae; parts used -leaves, seeds), 12) Tribulus terristeris (Caltrop, Zygophyllaceae parts used-seeds), 13) Asphaltum bitumen (Shilajit; parts used - pitch), 14) Mucuna pruriens (Kapi kacchu; Fabaceae, parts used- seed), 15) Asparagus racemosus (Shatawari, Family- Liliaceae, parts used- root), 16) Erythroxylem catuaba (Catuaba, FamilyErythroxylaceae, parts used- bark), 17) Ipomoea digitata (Vidari kandha, Family- Convolvulaceae; parts used- root), 18) Anacyclus pyrethrum (Akarakarabha, Family- Compositae, parts usedroot ), and 19) Allium tuberosum (Chienese chive, Family- Zingiberaceae; parts used- seed) (Saxena et al., 2012; Sumalatha et al., 2010; Yakubu et al., 2008).

\section{Conclusion}

Safed musli (Chlorophytum borivilianum) is a rare Indian medicinal plant. Safed musli is also considered as one of the divine Indian herbal medicine with many pharmaceutical applications, used in the treatment of male impotence, oligozoospermia and erectile dysfunction, arthritis, diabetes, rheumatism, joint pain, and immunity booster. The powdered form of the tubers can be used daily as a general health tonic. The consumption of safed musli leaves as vegetables also provided immunity against many viral, fungal and bacterial infections. The high demand for tubers for medicinal purpose makes it a valuable crop. At the same time, the tubers are traditionally used as planting materials.

Safed musli (Chlorophytum borivilianum) plays an important role in primary health care and therefore, becomes an integral part of human life to combat many health disorders. Safed musli (Chlorophytum borivilianum) mucilage are pharmaceutically important polysaccharide with commercial importance. Therefore, Safed musli (Chlorophytum borivilianum) is considered as a valuable herbal medicine for the correction of many health disorders without any side effects. 


\section{Conflict of interest statement}

Authors declare that they have no conflict of interest.

\section{References}

Akki BG, Patil SH (2006) Preliminary phytochemical investigation and in-vitro antistress activity of safed musli - Chlorophytum borivilianum. Indian Drugs. 43 (11), 878-880.

Ashraf MF, Aziz MA, Kemat N, Ismail I (2014) Effect of cytokinin types, concentrations and their interactions on in vitro shoot regeneration of Chlorophytum borivilianum Sant. \& Fernandez. Electronic J. Biotechnol. 17, 275-279.

Chakraborthy GS, Aeri V (2009) Immunomodulatory activity of Chlorophytum borivilianum. Pharmacologyonline. 3: 54-57.

Chakraborthy GS, Aeri V (2010) Pharmacognostical studies of potential herbChlorophytum borivilianum. IJPSR. 1(4), 1320.

Deore SL and Khadabadi SS (2007) In vitro antimicrobial studies of Chlorophytum borivilianum (Liliaceae) root extracts, Asian J. Microbiol. Biotech. Env. Sci. 9(4), 807-809.

Deore SL and Khadabadi SS (2008a) AntiInflammatory and antioxidant activity of Chlorophytum borivilianum root extracts. Asian J. Chem. 20(2), 983-986.

Deore SL and Khadabadi SS (2008b) Standardisation and pharmaceutical evaluation of Chlorophytum borivilianum mucilage. Rasayan J. Chem. 4, 887-892.

Deore SL and Khadabadi SS (2009) Larvicidal activity of the saponin fractions of Chlorophytum borivilianum. J. Entomol. Nematol. 1(5), 64-66.

Deore SL and Khadabadi SS (2010) Isolation and characterization of phytoconstituents from Chlorophytum borivilianum. Phcog Res. 2:343-349.

Desale P (2013) Safed Musli: Herbal Viagra for Male Impotence. Journal of Medicinal Plants Studies, 1(3), 91-97.

Elizabeth KG (2001) Safed musli A promising medicinal plant. Indian Journal of Areca nut, Spices Med. Plants. 5(2), 65-69.

Giribabu N, Kumar KE, Rekha SS, Sekaran Muniandy S, Salleh N (2014) Chlorophytum borivilianum (Safed Musli) root extract prevents impairment in characteristics and elevation of oxidative stress in sperm of streptozotocin-induced adult male diabetic Wistar rats. BMC Compl. Alt. Med. 14, 291.

Haque R, Bera T (2011) Peer Reviewed Literature on medicinal activity of Chlorophytum borivilianum Commercial Medicinal Plant. Int. J. Drug Dev. Res. 3(1), 116-1130.

Bhat MH, Fayaz M, Kumar A, Jain AK (2018) Phytochemical, Pharmacological and Nutritional Profile of Chlorophytum tuberosum (Roxb.) Baker (Safed musli): a Review. Int. J. Theor. Appl. Sci. 10(1), 93-99.

Kenjale R, Shah R, Sathaye S (2008) Effects of chlorophytum borivilianum on sexual behavior and sperm count in male rats. Phytotherapy Res. 22(6), 796-801.

Kothari SK (2004) Safed Musli (Chlorophytum borivilianum) revisited. J. Med. Arom. Plant Sci. 26, 60-63.

Kothari, S. K., Sigh, K., 2003. Production technique for the cultivation of safed musli (Chlorophytum borivilianum). J Hortic. Sci Biotech. 8(2), 261-264.

Kumar M, Gangwar R, Sagar S, Chaudhary S, Kumar Y, Kumar V (2018) Micropropagation of Safed musli (Chlorophytum borivilianum)an Endangered Medicinal Herb. TECHNOFAME. 7 (1), 26-31.

Lattoo SK, Bamotra S, Sapru Dhar R, Khan S, Dhar AK (2006) Rapid plant regeneration and analysis of genetic fidelity of in vitro derived plants of Chlorophytum arundinaceum Baker-An endangered medicinal herb. Plant Cell Rep. 25, 499-506.

Malabadi RB (2008) Production of edible vaccines for oral immunization in transgenic plants, current and future prospective. J. Phytol. Res. 21(1), 1-10.

Malabadi RB, Vijay Kumar S (2008) Evaluation of antifungal property of medicinal plants. J. Phytol. Res. 21(1), 139-142.

Malabadi RB, Mulgund GS, Nataraja K (2009) Triacontanol induced somatic embryogenesis and plantlet regeneration in Catharanthus roseus. J. Med. Arom. Plant Sci. 31, 147-151.

Malabadi RB, Mulgund GS, Nataraja K (2010a) Evaluation of antifungal activity of selected medicinal plants. J. Med. Arom. Plant Sci. 32(1), 42-45.

Malabadi RB, Parashar A, Ganguly A, Suresh MR 
(2010b) Expression of Dengue virus envelope protein in a different plant system. Faculty Research and Development day, Faculty of Pharmacy and Pharmaceutical Sciences, University of Alberta, Edmonton, Canada, 19th November 2010. Abstract No-69, page no-31.

Malabadi RB, Ganguly A, Teixeira da Silva JA, Parashar A, Suresh MR, Sunwoo HH (2011) Overview of plant-derived vaccine antigens: dengue virus. J. Pharm. Pharm. Sci. 14, 400413.

Malabadi RB, Vijayakumar S, Mulgund GS, Nataraja K (2011) Induction of somatic embryogenesis in Papaya (Carica papaya). Res. Biotechnol. 2(5), 40-55.

Malabadi RB, Chalannavar RK, Meti NT, Mulgund GS, Nataraja K, Vijayakumar S (2012a) Synthesis of antimicrobial silver nanoparticles by callus cultures and in vitro derived plants of Catharanthus roseus. Res. Pharmacy. 2(6), 1831.

Malabadi RB, Meti NT, Mulgund GS, Nataraja K, Vijayakumar S (2012b) Synthesis of silver nanoparticles from in vitro derived plants and callus cultures of Costus speciosus (Koen.); Assessment of antibacterial activity. Res. Plant Biol. 2(4), 32-42.

Malabadi RB, Mulgund GS, Meti NT, Nataraja K, Vijayakumar S (2012c) Antibacterial activity of silver nanoparticles synthesized by using whole plant extracts of Clitoria ternatea. Res. Pharmacy. 2(4), 10-21.

Malabadi RB, Lokare-Naik S, Meti NT, Mulgund GS, Nataraja K, Vijayakumar S (2012d) Synthesis of silver nanoparticles from in vitro derived plants and callus cultures of Clitoria ternatea; Evaluation of antimicrobial activity. Res. Biotechnol. 3(5), 26- 38.

Malabadi RB, Chalannavar RK, Sowmyashree K, Supriya S, Nityasree BR, Gleiser RM, Meti NT, Vijayakumar S, Mulgund GS, Gani RS, Nasalapure A, Chougale R, Masti S, Chougale A, Divakar MS, Kasai D, Odhav B, Baijnath $\mathrm{H}$ (2016a) Ebola virus: Updates on plant made vaccine development. Int. J. Res. Sci. Innov. 3(6), 4-12.

Malabadi RB, Chalannavar RK, Meti NT, Vijayakumar S, Mulgund GS (2016b) Plant viral expression vectors and Agroinfilteration: A literature review update. Int. J. Res. Sci. Innov. 3(IV), 32- 36.

Malabadi RB, Chalannavar RK Meti NT, Gani RS,
Vijayakumar S Mulgund GS, Masti S Chougale R, Odhav B, Sowmyashree K, Supriya S, Nityasree BR, Divakar MS (2016c) Insulin plant, Costus speciosus: Ethnobotany and pharmacological updates. Int. J. Curr. Res. Biosci. Plant Biol. 3(7), 151-161.

Malabadi RB, Chalannavar RK, Meti NT, Vijayakumar S,Mulgund GS, Gani RS, Supriya S, Sowmyashree K, Nityasree BR, Chougale A, Divakar MS (2016d) Antidiabetic Plant, Gymnema sylvestre R. Br., (Madhunashini): Ethnobotany, Phytochemistry and Pharmacological Updates. Int. J. Curr. Trends Pharmacobiol. Med. Sci. 1(4): 1-17.

Malabadi RB, Chalannavar RK, Meti NT, Gani RS, Vijayakumar S, Mulgund GS, Masti S, Chougale R, Odhav B, Sowmyashree K, Supriya S, Nityasree BR, Divakar MS (2016e) Insulin Plant, Costus speciosus: Ethnobotany and Pharmacological Updates. Int. J. Curr. Res. Biosci. Plant Biol. 3(7), 151- 161.

Malabadi RB, Chalannavar RK, Supriya S, Nityasree BR,Sowmyashree K, Gangadhar S. Mulgund GS, Meti NT (2017a) Dengue virus disease: Recent updates on vaccine development. Int. J. Res. Sci. Innov. 4(7), 0829.

Malabadi RB, Chalannavar RK, Supriya S, Nityasree BR, Sowmyashree K, Gangadhar S. Mulgund GS, Meti NT (2017b) Dengue Virus Disease: Current updates on the use of Carica papaya leaf extract as a potential herbal medicine. Int. J. Res. Sci. Innov. 4(8), 36-50.

Mayank T, Dixit VK (2008) A review on some important medicinal plants of Chlorophytum spp. Plant Rev. 2: 168-172.

Purohit SD, Dave A, Kukda G (1994) Micropropagation of safed musli (Chlorophytum borivilianum), a rare Indian medicinal herb. Plant Cell Tissue Organ Cult. $39,93-96$.

Rungsung W, Dutta S, Das D, Hazra J (2013) A brief review on the botanical aspects and therapeutic potentials of important Indian medicinal plants. International Journal of Herbal Medicine. 1 (3): 38-45.

Samantaray S, Kumar SV, Maiti S (2009) Direct shoot regeneration from immature inflorescence cultures of Chlorophytum arundinaceum and Chlorophytum borivilianum. Biologia 64, 305-309.

Saxena A, Prakash P, Porwal M, Sissodia N, 
Sharma P (2012) Erectile dysfunction: A review and herbs used for its treatment. Int. J. Green Pharmacy. 6, 109-117.

Sharma VK, Mazumdar B (2012) Versatility of Safed musli (Indian Viagra) in Human Ailments. Nutraceuticals. 1, 1-7.

Shrivastava A, Patel A, Dwivedi S (2016) Microprogation of endangered medicinal herb Chlorophytum borivilianum Sant. Et Fernand. J. Environ. Res. Devel. 10(3), 486-491.

Singh D, Pokhriyal B, Joshi YM, Vilasrao Kadam (2012) Phytopharmacological aspects of Chlorophytum borivilianum (safed musli): A review. Int. J. Res. Pharm. Chem. 2(3), 853-859. Singh A and Chauhan HS (2003) Safed musli
(Chlorophytum borivilianum) distribution, biodiversity and cultivation. J. Med. Arom. Plant Sci. 25, 712-719.

Sumalatha K, Kumar SA, Lakshmi SM (2010) Review on natural aphrodisiac potentials to treat sexual dysfunction. Int. J. Pharm. Ther. 1, 10-18.

Thakur M, Dixit VK (2006) Effect of $C$. borivilianum on androgenic and sexual behaviour of male rats. Indian Drugs. 43, 300-306.

Yakubu MT, Adewmi MA, Oladiji TA (2008) Male sexual dysfunction and methods used in assessing medicinal plants with aphrodisiac potentials. Res. J. Med. Plants. 2, 66-73.

\section{How to cite this article:}

Malabadi, R. B., Chalannavar, R. K., 2020. Safed musli (Chlorophytum borivilianum): Ethnobotany, phytochemistry and pharmacological updates. Int. J. Curr. Res. Biosci. Plant Biol. 7(11), 25-31.

doi: https://doi.org/10.20546/ijcrbp.2020.711.003 